\title{
ESCRITAS COMPARTILHADAS
}

A Revista Sul-Americana de Filosofia e Educação (RESAFE) apresenta seu número 22.

Até o último momento que antecede a publicação de um número de uma revista, há um trabalho de edição que ocorre em uma espécie de "bastidor". Textos chegam, textos saem, textos voltam... Seguem anônimos para um encontro com pares os pareceristas - que dialogam com as linhas que chegam até eles. Evamos querendo ouvir as vozes que chegam e se cruzam, configurando belas conversas. São vozes que se somam para que tudo aconteça da melhor forma possível. Quando vemos, já são várias. Avolumam-se. $\mathrm{E}$ então ficamos na torcida para que o número seja logo publicado, o que permitirá que essas escritas sejam, finalmente, compartilhadas com seus leitores.

É por tudo isso que agradecemos autores, pareceristas e leitores: pelo que fazem. Obrigada!

São oito artigos, uma resenha e um diálogo. De forma mais próxima ou mais distante, os textos dialogam entre si, uma vez que todos conversam nos espaços da filosofia e da educação.

Não sabemos onde esses diálogos ou essas conversas irão parar...

Esperamos, inclusive e, sobretudo, que não parem.

Um bom começo é o sumário.

Boa leitura!

Paula Ramos de Oliveira co-editora. 